\title{
Biosynthesis of 2-Deoxystreptamine by Three Crucial Enzymes in Streptomyces fradiae NBRC 12773
}

\author{
Fumitaka Kudo, Yasuhito Yamamoto, Kenichi Yokoyama, Tadashi Eguchi, \\ Katsumi Kakinuma
}

Received: August 19, 2005 / Accepted: November 20, 2005

(C) Japan Antibiotics Research Association

\begin{abstract}
NeoA, B, and C encoded in the neomycin biosynthetic gene cluster have been enzymatically confirmed to be responsible to the formation of 2deoxystreptamine (DOS) in Streptomyces fradiae. NeoC was functionally characterized as 2-deoxy-scyllo-inosose synthase, which catalyzes the carbocycle formation from D-glucose-6-phosphate to 2-deoxy-scyllo-inosose. Further, NeoA appeared to catalyze the oxidation of 2-deoxy-scyllo-inosamine (DOIA) with $\operatorname{NAD}(\mathrm{P})^{+}$ forming 3-amino-2,3-dideoxy-scyllo-inosose (amino-DOI). Consequently, NeoA was characterized as 2-deoxy-scylloinosamine dehydrogenase. Finally, amino-DOI produced by NeoA from DOIA was transformed into DOS by NeoB. Since NeoB (Neo6) was also reported to be L-glutamine:2deoxy-scyllo-inosose aminotransferase, all the enzymes in the DOS biosynthesis were characterized for the first time.
\end{abstract}

Keywords 2-deoxy-scyllo-inosose synthase, L-glutamine:2-deoxy-scyllo-inosose aminotransferase, 2-deoxyscyllo-inosamine dehydrogenase, 2-deoxystreptamine, neomycin biosynthetic gene cluster

\section{Introduction}

Aminoglycosides are among clinically important antibiotics for long time and include kanamycin, neomycin, gentamicin, streptomycin etc. It has been shown that aminoglycosides specifically bind to the bacterial ribosomal RNA and inhibit the bacterial protein biosynthesis [1]. Based on the specific interaction with RNA molecules, many applications such as anti-HIV infection $[2,3]$ and anti-plasmid $[4,5]$, are continuously investigated [6 8]. Thus, the creation of a library for structurally diverse aminoglycoside molecules is strongly desired. Biosynthetic approach appears to be promising for this purpose, so that the detailed studies will be necessary for construction of an efficient biosynthetic system.

Concerning the biosynthesis of 2-deoxystreptamine (DOS)-containing aminoglycosides, the biosynthetic study of butirosin in our laboratory leads on the genetic and enzymatic level. 2-Deoxy-scyllo-inosose synthase (DOIS), which catalyzes the first crucial carbocycle formation from D-glucose-6-phosphate in the DOS biosynthesis, has been purified from the butirosin producer Bacillus circulans and its gene $\operatorname{btr} C$ was identified based on the $N$-terminal sequence $[9,10]$. Subsequently, the butirosin biosynthetic gene (btr) cluster was identified [11, 12]. Also, BtrS and $\mathrm{BtrD}$ in the cluster were successfully characterized as a doubly functional L-glutamine:2-deoxy-scyllo-inosose (DOI) aminotransferase [13 15] in the DOS biosynthesis and a secondary metabolism specific TDP-glucosamine synthase [16], respectively.

During the recent two years, several groups reported the similar DOS-containing aminocyclitol biosynthetic gene clusters from actinomycetes including kanamycin, gentamicin, tobramycin, ribostamycin, and neomycin

F. Kudo, Y. Yamamoto, K. Yokoyama, K. Kakinuma: Department of Chemistry, Tokyo Institute of Technology, 2-12-1, O-okayama, Meguro-ku, Tokyo 152-8551, Japan
T. Eguchi (Corresponding author): Department of Chemistry \& Materials Science, Tokyo Institute of Technology, 2-12-1, O-okayama, Meguro-ku, Tokyo 152-8551, Japan.

E-mail: eguchi@cms.titech.ac.jp 


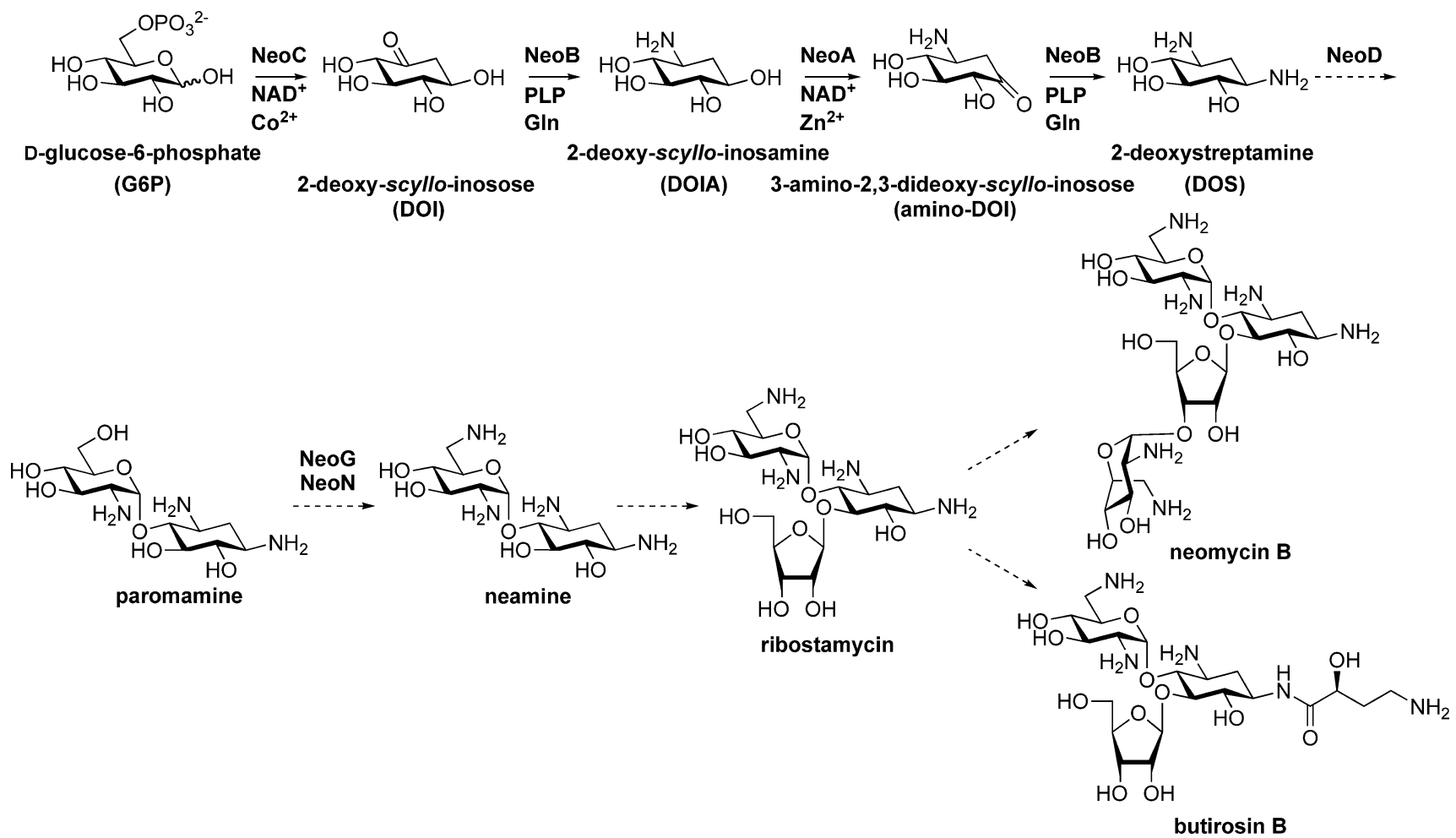

Scheme 1 Biosynthesis of neomycin and butirosin.

Solid lines: The elucidated biosynthetic steps on the enzyme reaction level. Broken lines: Not elucidated yet.

producers, and the functions of the genes have been proposed [17 23]. Among those, three genes neoA (neo5), nеoB (neo6), and neoC (neo7) in the neomycin biosynthetic gene cluster have been recently proposed to be responsible to the formation of DOS by comparative analysis of the genes [22]. In the present paper, we clarified the functions of three genes neo $A$, nеo $B$, and neoC, using the separately expressed proteins derived from the independently identified genes in Streptomyces fradiae NBRC 12773.

\section{Results and Discussion}

At first, the neomycin biosynthetic (neo) gene cluster was obtained from $S$. fradiae NBRC 12773 by screening of the genomic library using a probe of the L-glutamine:DOI aminotransferase gene [24]. The DNA sequence data of the neo gene cluster in S. fradiae NBRC 12773 has been deposited to the DDBJ under accession number AB211959. The present identified neo genes were basically same as those recently reported by Spencer group [22]. Obvious differences were found in the size of neoD, neoE, and neoO corresponding to neo8, neo9, and neo19, respectively.

As Spencer group has reported [22], a comparative analysis of all known DOS-containing antibiotic
Table 1 Six conserved genes for the neamine biosynthesis

\begin{tabular}{ccl}
\hline neo gene cluster & btr gene cluster & \multicolumn{1}{c}{ Functions } \\
\hline neoA (neo5) & btrE & DOIA dehydrogenase \\
neoB (neo6) & btrS & GIn:DOI aminotransferase \\
neoC (neo7) & btrC & DOI synthase \\
neoD (neo8) & btrM & Putative glycosyltransferase \\
neoG (neo11) & btrQ & Putative dehydrogenase \\
neoN (neo18) & btrB & Putative aminotransferase \\
\hline
\end{tabular}

biosynthetic gene clusters by sequence similarity of the encoding proteins, clearly showed the six conserved genes (Table 1$)$; i.e. DOIS gene (btrC, neoC); L-glutamine:DOI aminotransferase gene (btr $S$, nеoB); a putative glycosyltransferase gene (btrM, neoD); a putative aminotransferase (similar to glutamate-1-semialdehyde 2,1aminomutase) gene (btrB, neoN); a putative alcohol dehydrogenase gene (btrE, neoA); another putative dehydrogenase (similar to chorine dehydrogenase and related flavoproteins) gene $(b \operatorname{tr} Q$, neo $G)$. These six genes thus are now considered to be involved in the biosynthesis of neamine, which is the core structure of DOS-containing 


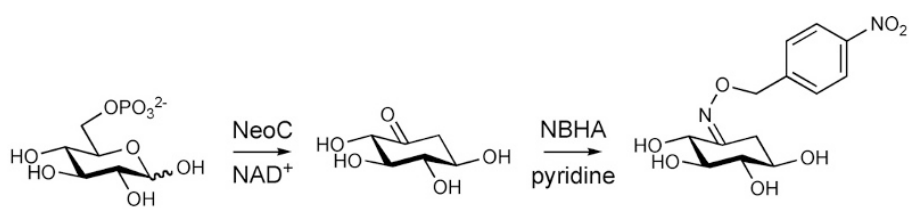

(A)

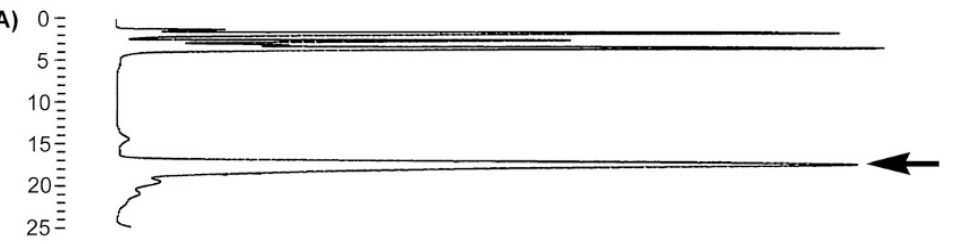

(B)

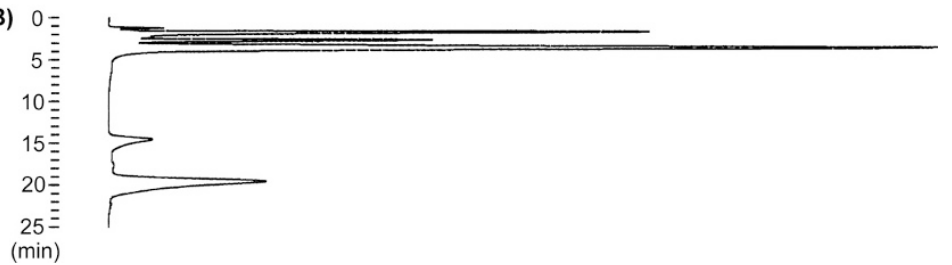

Fig. 1 DOIS activity of NeoC (HPLC analysis).

Analytical HPLC traces showing the NeoC catalyzed formation of DOI, which was converted to the nitrobenzyl oxime derivative using 4-nitrobenzylhydroxylamine and pyridine at $60^{\circ} \mathrm{C}$ for 1 hour. Arrow shows the peak for the DOI-nitrobenzyl oxime derivative (absorbance at $262 \mathrm{~nm}$ ), which was confirmed by co-injection with the authentic compound [26]. (A) NeoC reaction with D-glucose-6-phosphate (G6P) and $\mathrm{NAD}^{+}$. (b) Control reaction without G6P. Some unidentified peaks were observed in the HPLC traces, which may be derived from impurities in the partially pure protein solution.

aminocyclitol antibiotics (Scheme 1). The functions of $\mathrm{NeoB}, \mathrm{NeoC}$, and NeoD in the biosynthesis of neomycin were easily assigned based on our previous reports about the functions of the corresponding btr genes. In fact, NeoB (Neo6) was clearly reported as L-glutamine:DOI aminotransferase on the enzyme reaction level, although the forward reaction of the second transamination in the DOS biosynthesis has not been examined yet [22]. The neoA gene is to encode a zinc-containing alcohol dehydrogenase, which generally uses $\mathrm{NAD}^{+} / \mathrm{NADP}^{+}$as a cofactor. Since the addition of 2-deoxy-scyllo-inosamine (DOIA) and $\mathrm{NAD}^{+}$into the cell free system of $S$. fradiae was reported to increase the DOS production [25], it seems likely that NeoA could catalyze the oxidation of DOIA because it is the only $\mathrm{NAD}(\mathrm{P})^{+}$dependent dehydrogenase among the conserved proteins. The remaining steps from Dglucose-6-phosphate into neamine are the transformations of the hydroxy group at C-6 of the glucosamine moiety in paromamine. NeoG and $\mathrm{NeoN}$ have been thus assigned as a dehydrogenase and an aminotransferase in the oxidation and transamination at the position, respectively (Scheme 1).

To confirm whether three continuous enzymes, NeoA, $\mathrm{NeoB}$, and $\mathrm{NeoC}$ are responsible to the formation of DOS or not, these were separately expressed in Escherichia coli. In the case of $\mathrm{NeoC}$, although the expressed protein was mostly observed in the insoluble pellet, the soluble $\mathrm{NeoC}$ was partially purified by the DEAE ion exchange chromatography and the enzyme activity was analyzed according to the previously reported method [26]. As shown in Fig. 1, NeoC clearly turned out to have DOIS activity in the DOS biosynthesis. Although the $C$-terminus peptide of $\mathrm{NeoC}$, which is relatively longer than other DOISs, appears to be unnecessary for the activity, the precise function is not unclear at the moment.

The neoA gene was also expressed in E. coli and the resulting product $\mathrm{NeoA}$ was examined without purification for the oxidation of DOIA with either $\mathrm{NAD}^{+}$or $\mathrm{NADP}^{+}$in the presence of $\mathrm{Zn}^{2+}$ ion. The formation of the expected enzyme reaction product, 3-amino-2,3-dideoxy-scylloinosose (amino-DOI), can be analyzed on HPLC by conversion to the $N$-acetyl nitrobenzyl oxime derivative as previously reported [15]. Thus, after the NeoA enzyme reaction, the mixture was treated in situ with $\mathrm{Ac}_{2} \mathrm{O}$ for $\mathrm{N}$ acetylation and the resulting $\mathrm{N}$-acetamide was further converted to the nitrobenzyl oxime derivative with 4nitrobenzylhydroxylamine (NBHA). After the partial purification using a cartridge column, the resulting samples were analyzed by HPLC (Fig. 2). As a result, the crude cell free extract of $E$. coli containing the expressed NeoA protein appeared to produce amino-DOI, but not in a control reaction without NeoA protein (derived from E. coli harboring the pET30 vector). Also, both $\mathrm{NAD}^{+}$and 


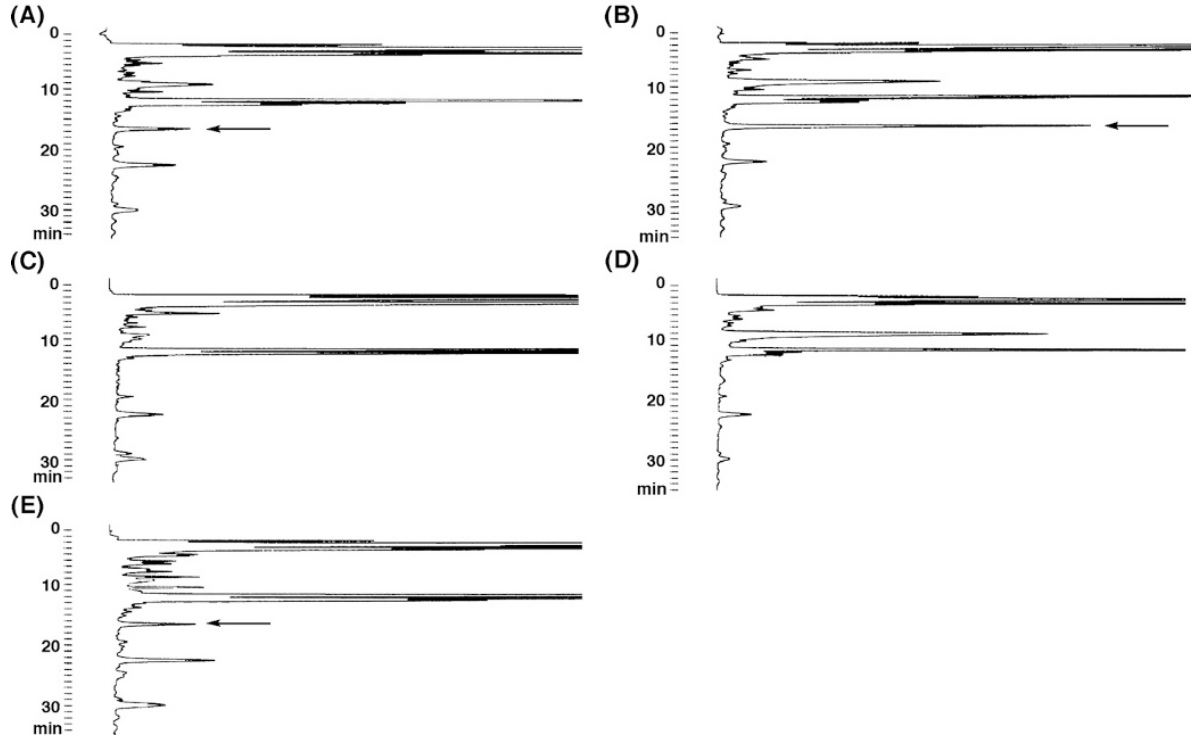

Fig. 2 Amino-DOI formation from DOIA by NeoA (HPLC analysis).

Arrows at 17 minutes show the peak for the $\mathrm{N}$-acetyl-nitrobenzyl oxime derivative of amino-DOI. (A) NeoA reaction with DOIA and $\mathrm{NAD}^{+}$. (B) Co-injection with the authentic compound in addition to (A). (C) Control reaction using the cell free extract of E. coli containing pET30 vector only with DOIA and NAD ${ }^{+}$. (D) Without DOIA. (E) NADP ${ }^{+}$instead of $\mathrm{NAD}^{+}$. A peak at 9 minutes was the degradation product from 4-nitrobenzylhydroxylamine (NBHA), which was not sometimes removed by Sep-Pak purification.

$\mathrm{NADP}^{+}$cofactor were found to be effective for the NeoA catalyzed oxidation. These results thus clearly confirmed that NeoA catalyzed the oxidation of DOIA using $\operatorname{NAD}(\mathrm{P})^{+}$in the DOS biosynthesis.

Sequence alignment of NeoA, BtrE and the structurally elucidated similar zinc-containing $\mathrm{NAD}(\mathrm{P})^{+}$dependent alcohol dehydrogenases (ADHs), BaKR (Ketose reductase, Bemisia argentifolii, 1E3J) [27], PaADH (ADH, Pseudomonas aeruginosa, 1LLU) [28], htADH (ADH, $B$. stearothermophilus, 1RJW) [29], is shown in Fig. 3. Based on the crystal structural studies, two zinc coordination motifs for catalytic (+ in Fig. 3) and structural (\# in Fig. 3) zincs were shown to be important to construct the active site and are highly conserved in this family. Most of these amino acids are conserved in NeoA and thus NeoA appears to be a typical zinc-containing $\mathrm{ADH}$. On the other hand, $\mathrm{BtrE}$ does not contain any residue of these. Therefore, it is hypothesized that BtrE may be inactive in the antibiotic biosynthesis or catalyze the reaction by a different manner.

NeoB (Neo6) was reported to catalyze the reverse reaction of the transamination of amino-DOI to DOS as well as BtrS in the butirosin biosynthesis [15, 22]. However, its forward reaction has never been examined due to the difficulty of the preparation of unprotected aminoDOI. Thus, amino-DOI produced by the NeoA reaction was continuously used as substrate for the natural forward transamination catalyzed by NeoB in the DOS biosynthesis. The continuous conversion of DOIA into DOS consisting of the oxidation of DOIA and the transamination of aminoDOI was thus examined using the cell free extracts containing NeoA and NeoB (Fig. 4). As expected, DOS was produced by the combined use of $\mathrm{NeoA}$ and $\mathrm{NeoB}$ with DOIA, NAD ${ }^{+}$, PLP and L-glutamine (Fig. 4A). Since the cell free extract of $E$. coli harboring the expression plasmid of NeoB did not produce DOS at all, it was obvious that the expressed NeoA protein was absolutely required for this two-step enzymatic conversion as DOIA dehydrogenase. Therefore, the present study confirmed that NeoA is responsible to the $\mathrm{NAD}(\mathrm{P})^{+}$-dependent dehydrogenation of DOIA in the DOS biosynthesis. Also, this is the first report showing the transamination of amino-DOI using the expressed protein. Consequently, DOS biosynthesis from D-glucose-6-phosphate was established at the enzyme reaction level for the first time as shown in Scheme 1.

In summary, we have identified the neomycin biosynthetic gene cluster in S. fradiae NBRC12773 and NeoA, B, and C 


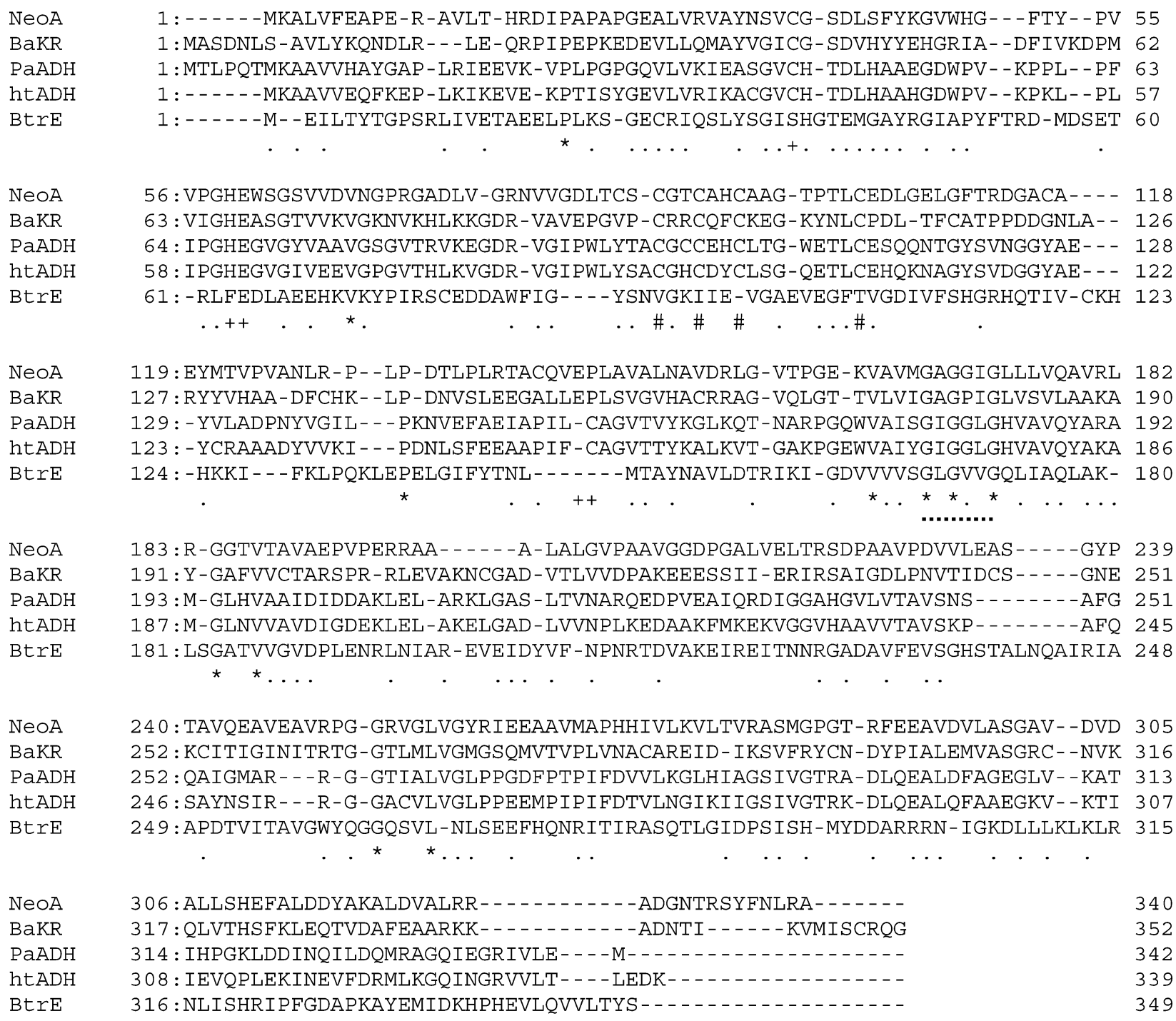

Fig. 3 Sequence alignment of zinc containing alcohol dehydrogenases (ADH) with NeoA.

NeoA: DOIA dehydrogenase (S. fradiae), BaKR: Ketose reductase (Bemisia argentifolii), PaADH: alcohol dehydrogenase (Pseudomonas aeruginosa), htADH: alcohol dehydrogenase (B. stearothermophilus), BtrE: putative dehydrogenase (B. circulans). The conserved amino acid residues are marked with asterisk and similar amino acid residues are marked with period. +: catalytic zinc ion coordination residues. \#: structural zinc coordination cysteines. These two zinc-binding motifs are not conserved in BtrE. The Rossman fold is shown as a dotted line.

have been confirmed to be responsible to the formation of DOS in the neomycin biosynthesis. The precise enzyme reaction mechanism in the DOS biosynthesis, especially the NeoA-catalyzed oxidation of DOIA, is unclear at the molecular level. In addition, many key reactions except for the DOS formation in a whole biosynthesis still remain to be solved on the enzyme reaction level. The detailed functional analysis of the genes beyond neo $A$, nеoB, and neo $C$ should be necessary to elucidate the biosynthesis and open the way to the combinatorial aminoglycoside production by the biosynthetic enzymes.

\section{Experimental}

\section{General}

Streptomyces fradiae NBRC 12773 was purchased from National Institute of Technology and Evaluation Biological Resource Center (Japan) and was cultured on agar or liquid medium according to the center's protocol. General DNA manipulations in Escherichia coli were performed according to the standard protocol [30]. E. coli DH5 $\alpha$ was used as a host strain for the routine subcloning of DNA 


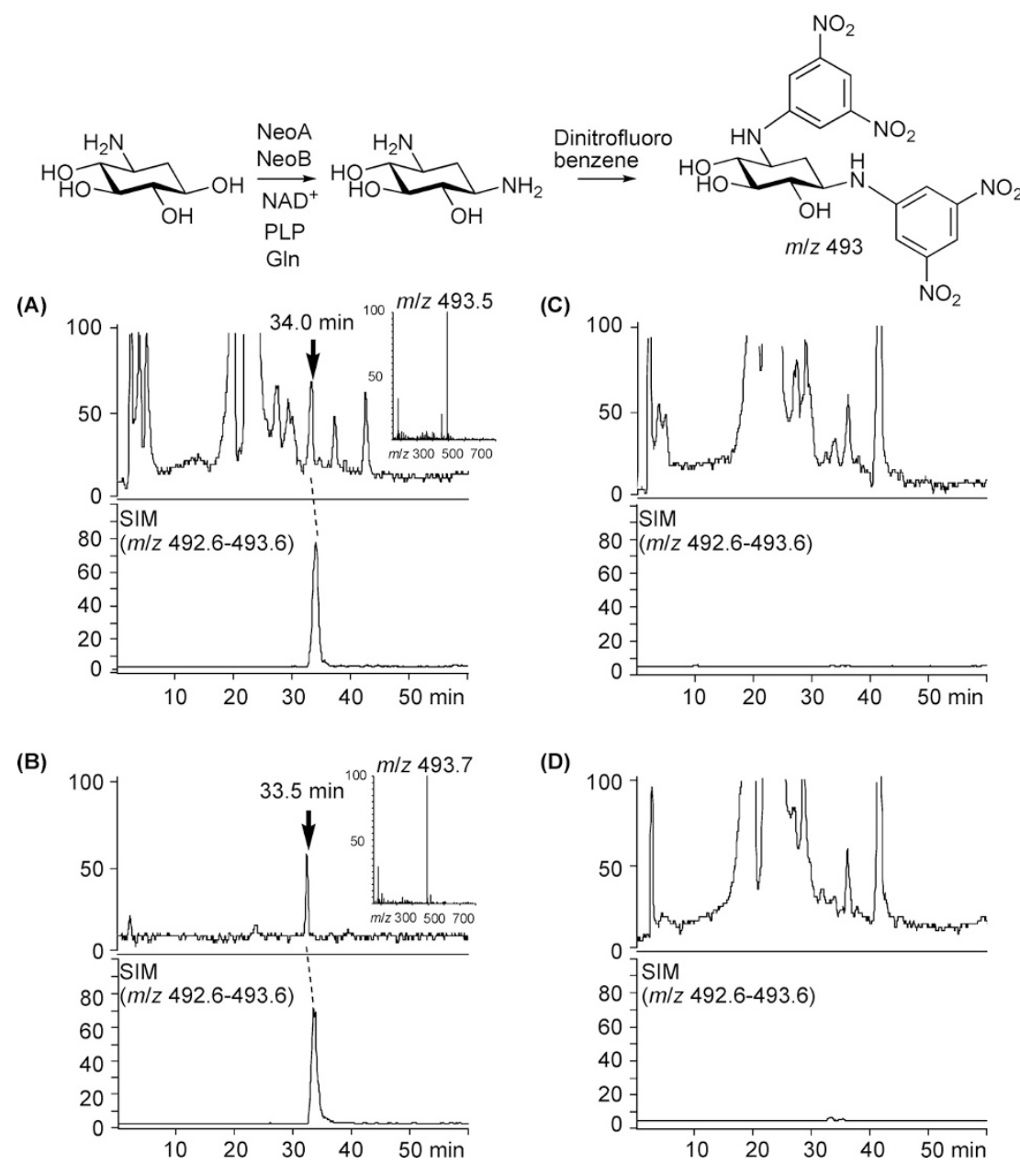

Fig. 4 DOS formation from DOIA by NeoA and NeoB (LC-MS analysis).

LC-MS spectra: TOP shows a trace of LC (relative abundance of $A_{350}$ ). Bottom shows a trace of the selected ion monitoring (SIM) between $\mathrm{m} / \mathrm{z}$ 492.6 493.6. ESI-MS was analyzed by the negative mode. The scale was normalized for all spectra. (A) All components containing NeoA, NeoB, DOIA, NAD ${ }^{+}$, PLP and GIn. (B) The authentic sample of DOS. (C) Without DOIA. (D) Without NeoA. Arrows at 33 34 minutes show the peak for the bisdinitrophenyl DOS derivative and the offset mass spectra were derived from the peak.

fragments. E. coli BL21(DE3) was used for expression of the neo genes. The plasmid pUC119 and LITMUS28 (New England Biolabs) were routinely used as a plasmid vector for subcloning and sequencing. The pT7-blue $\mathrm{T}$ vector (Novagen) was routinely used as a plasmid vector for the subcloning of PCR amplified DNA. The cosmid vector pOJ446 was used for construction of a cosmid library [31]. E. coli containing plasmid were cultured in Luria-Bertani (LB) medium with appropriate antibiotics at $37^{\circ} \mathrm{C}$ for over night to extract plasmids. Purification of plasmids was carried out with GFX micro Plasmid Prep Kit (Amersham Bioscience). A $100 \mu \mathrm{g} / \mathrm{ml}$ of ampicillin or $30 \mu \mathrm{g} / \mathrm{ml}$ of kanamycin was added to LB medium.

Oligonucleotides were purchased from Sigma Genosys. Restriction enzymes and modification enzymes were purchased from TaKaRa. PCR was performed by GeneAmp
PCR System 9700 (Perkin Elmer Applied Biosystems) using KOD-plus-DNA polymerase (TOYOBO) or LA-Taq DNA polymerase (TaKaRa). DNA sequence analysis was carried out with a LONG READER 4200 (Li-Cor) and a Thermo Sequenase Cycle Sequencing Kit according to the manufacturer's protocol. HPLC was performed on a Hitachi L-6250 Intelligent Pump equipped with a L-4000H UV Detector and a D-2500 Chromato-Integrator for the enzyme assay. A LCQ mass spectrometer (Finnigan) connected with NANOSPACE HPLC and SE-1 UV detector (Shiseido, Japan) equipped with a RP-18 GP column (Kanto Chemical, Japan) was used for the LC-MS analysis. A FPLC (Pharmacia Biotech.) was used for protein purification. Other chemicals were of highest grade commercially available. 


\section{Identification of the neo Gene Cluster in S. fradiae}

A large amount of chromosomal DNA from $S$. fradiae NBRC 12773 was extracted by the standard protocol from the cells cultured in a $200 \mathrm{ml}$ medium for 8 days [32]. The chromosomal DNA was partially digested with Sau3AI for 10 minutes and the restriction enzyme was denatured with the phenol-chloroform extraction. After the ethanol precipitation, the digested DNA fragments were treated with Calf intestine alkaline phosphatase (CIAP) at $50^{\circ} \mathrm{C}$ for 30 minutes and CIAP was denatured with the phenolchloroform extraction. A cosmid vector pOJ446 was separately digested with $H p a \mathrm{I}$, and after the treatment of CIAP, followed by digestion with BamHI. After the phenol-chloroform extraction and the ethanol precipitation, the resulting DNA was dissolved with TE buffer. The digested pOJ446 and the partially digested chromosomal DNA were ligated using DNA Ligation kit Ver.2 (TaKaRa). After the ethanol precipitation, the ligated DNA was dissolved with TE buffer. The resulting ligation mixture was packaged into $\lambda$ phage followed by phage transfection to E. coli XL1 Blue MRF' by Gigapack III Gold Packaging Extract (Stratagene) according to the manufacturer's protocol. The host strain E. coli XL1 Blue $\mathrm{MRF}^{\prime}$ was cultured in $3 \mathrm{ml}$ of $\mathrm{LB}$ containing $10 \mathrm{mM}$ $\mathrm{MgSO}_{4}$ and $0.2 \%$ maltose by $\mathrm{OD}_{600} 1-2.1 \mathrm{ml}$ of the culture was centrifuged and the resulting wet cells were suspended in a $10 \mathrm{mM} \mathrm{MgSO}_{4}$ up to $\mathrm{OD}_{600} 1$ for transfection.

The cosmid library of 2,000 clones in E. coli was directly screened by hybridization with a Dig labeled DNA probe, which was made from the PCR amplified DNA fragments for the partial gene of L-Gln:DOI aminotransferase by the DIG DNA Labeling Kit (Roche). PCR conditions were $94^{\circ} \mathrm{C}, 5$ minutes for denature, 30 cycles of $94^{\circ} \mathrm{C}, 30$ seconds, $62^{\circ} \mathrm{C}, 30$ seconds, $72^{\circ} \mathrm{C}, 30$ seconds for extension of DNA in $5 \mu 1$ of $2 \times \mathrm{GC}$ buffer II, $1.6 \mu \mathrm{l}$ of dNTP (2.5 mM each), $0.2 \mu \mathrm{l}$ of neoSP-F 5'-TGGGTCGCCTCCGGCTCCACCG-3' $(50 \mu \mathrm{M}), 0.2 \mu \mathrm{l}$ of neoSP-R 5'-GCAGCGGTTGCTGCCCATCAGC-3' $(50 \mu \mathrm{M}), 0.1 \mu \mathrm{l}$ of LA-Taq DNA polymerase, $1 \mu \mathrm{l}$ of template solution (10 $\mathrm{ng} / \mu \mathrm{l}$ of chromosomal DNA), and $1.9 \mu \mathrm{l}$ of water. The hybridization was carried out by standard manner and the hybridized DNA was detected by DIG Nucleic Acid Detection Kit with NBT/BCIP solution (Roche) according to the manufacturer's protocol.

Positive 16 clones were cultured and the cosmids were extracted by standard protocol. The cosmids were examined for whether they contained the L-Gln:DOI aminotransferase gene by PCR under the conditions as mentioned above followed by Southern hybridization with the same probe for screening after KpnI digestion. Among the positive cosmids, the cosmid cfra10 was randomly sequenced by a shotgun sequence method on doublestranded DNA templates (Hitachi Instruments Service). All gaps in the draft sequence were separately cloned from the cosmid cfra 10 and the DNA sequence was determined by a DNA sequencer. As a result, $39 \mathrm{kbp}$ of DNA sequence was determined. The ORFs were determined by FramePlot analysis [33] (www.nih.go.jp/ jun/cgi-bin/frameplot.pl) and blast homology search through web considering a possible Shine-Dargano sequence. The DNA sequence data of the neo gene cluster in S. fradiae NBRC 12773 has been deposited to the DDBJ, EMBL, and GenBank databases under accession number AB211959.

\section{Expression and Functional Analysis of the neoC Gene Encoding DOI Synthase}

The neoC gene was amplified by PCR from the cosmid cfra10 with primers neoC-F: 5'-GCCATATGCAGACCACCCGC-3' and neoC-R: 5'-GCGGGAAGCTTGCCGGCAC- $3^{\prime}$. PCR conditions were $94^{\circ} \mathrm{C}, 2$ miutes for denature, 25 cycles of $94^{\circ} \mathrm{C}, 15$ seconds, $52^{\circ} \mathrm{C}, 30$ seconds, $68^{\circ} \mathrm{C}, 70$ seconds for extension of DNA in $1 \mu \mathrm{l}$ of $10 \times$ KOD buffer, $1 \mu 1$ of dNTP $(2.0 \mathrm{mM}$ each $), 0.4 \mu \mathrm{l}$ of $\mathrm{MgSO}_{4}(25 \mathrm{mM}), 0.5 \mu \mathrm{l}$ of DMSO, $0.1 \mu \mathrm{l}$ of neoC-F $(50 \mu \mathrm{M}), 0.1 \mu \mathrm{l}$ of neoC-R $(50 \mu \mathrm{M}), 0.2 \mu \mathrm{l}$ of KOD-plus polymerase, $0.6 \mu \mathrm{l}$ of cfra10 (50 ng/ $\mu \mathrm{l})$, and $6.1 \mu \mathrm{l}$ of water. The amplified PCR product was digested with HindIII and the resulting DNA fragment was subcloned into the LITMUS28 previously digested with EcoRV and HindIII to obtain LITMUS28-neoC. After confirmation of the DNA sequence, the appropriate plasmid was digested with $N d e$ I and HindIII and the resulting DNA fragment was inserted into the corresponding site of pET30b (Novagen) to obtain pET-neoC. The pET-neoC was introduced into E. coli BL21(DE3) by a standard chemical transformation. The $E$. coli harboring pET-neoC was grown in a LB medium supplemented with $30 \mu \mathrm{g} / \mathrm{ml}$ of kanamycin at $37^{\circ} \mathrm{C}$ by $\mathrm{OD}_{600} \quad 0.7$ and a final $0.25 \mathrm{mM}$ of isopropyl $\beta$-Dthiogalactoside was added for induction of overexpression. The culture was continued at $18^{\circ} \mathrm{C}$ for over night and the cells were harvested by centrifugation $(6,000 \mathrm{rpm} \times 30$ minutes). The wet cells $(2 \mathrm{~g})$ were suspended in $20 \mathrm{ml}$ of $50 \mathrm{mM}$ Tris buffer ( $\mathrm{pH} 7.5$ ) containing $1 \mathrm{mM}$ of $\mathrm{CoCl}_{2}$ and $10 \%$ glycerol and disrupted by French Press (Thermo IEC). After centrifugation $(12,000 \mathrm{rpm} \times 30$ minutes $)$, the supernatant was loaded onto a DEAE-Sepharose Fast Flow column $(2.5 \times 10 \mathrm{~cm})$ previously equilibrated with the same buffer. NeoC was eluted with a linear gradient of $0 \sim 0.3 \mathrm{M}$ of $\mathrm{NaCl}$ in the same buffer. The fractions containing $\mathrm{NeoC}$ were combined and concentrated by ultrafiltration (VIVASPIN 20, Vivascience, Germany). DOI synthase reaction was carried out in $5 \mathrm{mM}$ of glucose-6-phosphate, 
$5 \mathrm{mM}$ of $\mathrm{NAD}^{+}$with the partially purified $\mathrm{NeoC}$, at $46^{\circ} \mathrm{C}$, for 2 hours. The product DOI was analyzed by previously reported method [26].

\section{Expression of the neo $A$ and $n e o B$ Genes}

The expression systems for the nеo $A$ and nеoB gene were constructed by same method for functional analysis of the neoC gene, except primers (neoA-F: 5'GCCATATGAAGGCTCTGGTG-3' and neoA-R: 5'GGGCCAAGCTTTCCTGAGGG-3' for the neo $A$ gene, neoB-F: 5'-GGCATATGGTCTCCCCGTTG-3' and neoBR: 5'-GCATGAAGCTTCCCGGTCC-3' for the neoB gene). The nеo $A$ and $п е о B$ gene were separately expressed by the same conditions mentioned above. The wet cells $(2 \mathrm{~g})$ harboring the nеo $A$ and neoB gene expression plasmid were independently suspended in $10 \mathrm{ml}$ of $50 \mathrm{mM}$ Tris buffer ( $\mathrm{pH}$ 8.0) containing $0.5 \mathrm{mM}$ of $\mathrm{ZnCl}_{2}$ and disrupted by French Press (Thermo IEC). After centrifugation $(12,000 \mathrm{rpm} \times 30$ minutes $)$, the supernatants were independently used for enzyme reactions as the cell free extracts.

\section{Detection of the Amino-DOI Formation from DOIA by NeoA}

The enzyme reaction was performed using the cell free extracts of NeoA with $5 \mathrm{mM}$ of DOIA, $10 \mathrm{mM}$ of $\mathrm{NAD}^{+}$in total $200 \mu \mathrm{l}$ of $50 \mathrm{mM}$ Tris buffer ( $\mathrm{pH}$ 8.0) containing $0.5 \mathrm{mM}$ of $\mathrm{ZnCl}_{2}$ at $28^{\circ} \mathrm{C}$ for 12 hours. To the resulting mixture $(100 \mu \mathrm{l})$ was added $300 \mu \mathrm{l}$ of acetic anhydride, and then reacted at $37^{\circ} \mathrm{C}$ for 3 hours. After removal of solvent by a centrifugal evaporator, the residue was dissolved with $200 \mu \mathrm{l}$ of methanol, and followed by addition of $100 \mu \mathrm{l}$ of 4-nitrobenzylhydroxylamine solution in pyridine $(10 \mathrm{mg} / \mathrm{ml})$, and then reacted $60^{\circ} \mathrm{C}$ for 3 hours. The residue was dissolved with $2.1 \mathrm{ml}$ of $5 \%$ methanol in chloroform and the resultant solution was passed through the Sep-Pak ${ }^{\circledR}$ Plus Silica (Waters). The cartridge was washed with $6 \mathrm{ml}$ of $6.3 \%$ methanol in chloroform and the expected product, $\mathrm{N}$ acetyl nitrobenzyl oxime, was eluted with $5 \mathrm{ml}$ of $17 \%$ methanol in chloroform. After concentration of the solution, the residue was dissolved with $100 \mu \mathrm{l}$ of methanol. An aliquot of the solution $(5 \mu \mathrm{l})$ was injected into a HPLC (Hitachi) equipped with a PEGASIL ODS column $(4.6 \mathrm{~mm} \times 250 \mathrm{~mm}$, Senshu) and eluted with $30 \%$ aqueous methanol at a flow rate $1 \mathrm{ml} /$ minute at $40^{\circ} \mathrm{C}$. The elution was monitored by $254 \mathrm{~nm}$.

\section{DOS Formation from DOIA by NeoA and NeoB}

The enzyme reaction was performed using the cell free extracts of NeoA and $\mathrm{NeoB}$ with $5 \mathrm{mM}$ of DOIA, $5 \mathrm{mM}$ of $\mathrm{NAD}^{+}, 0.5 \mathrm{mM}$ of PLP, and $10 \mathrm{mM}$ of glutamine at $28^{\circ} \mathrm{C}$ for 12 hours. The resulting mixture $(50 \mu 1)$ was reacted with $25 \mu \mathrm{l}$ of $5 \%$ 2,4-dinitrofluorobenzene in methanol, $12.5 \mu \mathrm{l}$ of $\mathrm{DMSO}$, and $2.5 \mu \mathrm{l}$ of $2 \mathrm{M} \mathrm{NaOH}$ at $60^{\circ} \mathrm{C}$ for 1 hour. After removal of the solvent by a centrifugal evaporator, the residue was dissolved with ethyl acetate and water, and the ethyl acetare layer was separated and concentrated. The residue was dissolved with $2.1 \mathrm{ml}$ of $5 \%$ ethyl acetate in hexane. The resultant solution was passed through the Sep-Pak ${ }^{\circledR}$ Plus Silica (Waters). The cartridge was washed with $6 \mathrm{ml}$ of $10 \%$ ethyl acetate in hexane and the expected product, bisdinitrophenyl DOS, was eluted with $5 \mathrm{ml}$ of ethyl acetate. After concentration of the solution, the residue was dissolved with $100 \mu \mathrm{l}$ of methanol. An aliquot of the solution $(5 \mu \mathrm{l})$ was injected into a HPLC connected with LCQ mass spectrometer and eluted with $10 \%$ aqueous methanol for 10 minutes, and $62 \%$ aqueous methanol for 40 minutes at a flow rate $40 \mu \mathrm{l} /$ minute. The elution was monitored by $350 \mathrm{~nm}$ and analyzed by the negative mode. LC-ESI-MS (negative): $33 \sim 34$ minutes, $m / z 493.5(\mathrm{M}-\mathrm{H})^{-}$; calcd for $\mathrm{C}_{18} \mathrm{H}_{17} \mathrm{~N}_{6} \mathrm{O}_{11}: 493.382$.

\section{References}

1. Magnet S, Blanchard JS. Molecular insights into aminoglycoside action and resistance. Chem Rev 105: 477-498 (2005)

2. Lapidot A, Vijayabaskar V, Litovchick A, Yu J, James TL. Structure-activity relationships of aminoglycoside-arginine conjugates that bind HIV-1 RNAs as determined by fluorescence and NMR spectroscopy. FEBS Lett 577: 415-421 (2004)

3. McPike MP, Goodisman J, Dabrowiak JC. Specificity of neomycin analogues bound to the packaging region of human immunodeficiency virus type 1 RNA. Bioorg Med Chem 12: 1835-1843 (2004)

4. Denap JC, Thomas JR, Musk DJ, Hergenrother PJ. Combating drug-resistant bacteria: small molecule mimics of plasmid incompatibility as antiplasmid compounds. J Am Chem Soc 126: 15402-15404 (2004)

5. Thomas JR, Denap JC, Wong ML, Hergenrother PJ. The relationship between aminoglycosides' RNA binding proclivity and their antiplasmid effect on an IncB plasmid. Biochemistry 44: 6800-6808 (2005)

6. Tor Y. Targeting RNA with small molecules. Chembiochem 4: 998-1007 (2003)

7. Vicens Q, Westhof E. RNA as a drug target: the case of aminoglycosides. Chembiochem 4: 1018-1023 (2003)

8. Vakulenko SB, Mobashery S. Versatility of aminoglycosides and prospects for their future. Clin Microbiol Rev 16: 430-450 (2003)

9. Kudo F, Hosomi Y, Tamegai H, Kakinuma K. Purification 
and characterization of 2-deoxy-scyllo-inosose synthase derived from Bacillus circulans. A crucial carbocyclization enzyme in the biosynthesis of 2-deoxystreptaminecontaining aminoglycoside antibiotics. J Antibiot 52: 81-88 (1999)

10. Kudo F, Tamegai H, Fujiwara T, Tagami U, Hirayama K, Kakinuma K. Molecular cloning of the gene for the key carbocycle-forming enzyme in the biosynthesis of 2deoxystreptamine-containing aminocyclitol antibiotics and its comparison with dehydroquinate synthase. J Antibiot 52: 559-571 (1999)

11. Ota Y, Tamegai H, Kudo F, Kuriki H, Koike-Takeshita A, Eguchi T, Kakinuma K. Butirosin-biosynthetic gene cluster from Bacillus circulans. J Antibiot 53: 1158-1167 (2000)

12. Kudo F, Numakura M, Tamegai H, Yamamoto H, Eguchi T, Kakinuma K. Extended sequence and functional analysis of the butirosin biosynthetic gene cluster in Bacillus circulans SANK 72073. J Antibiot 58: 373-379 (2005)

13. Tamegai H, Nango E, Kuwahara M, Yamamoto H, Ota Y, Kuriki H, Eguchi T, Kakinuma K. Identification of L-glutamine: 2-deoxy-scyllo-inosose aminotransferase required for the biosynthesis of butirosin in Bacillus circulans. J Antibiot 55: 707-714 (2002)

14. Huang F, Li Y, Yu J, Spencer JB. Biosynthesis of aminoglycoside antibiotics: cloning, expression and characterisation of an aminotransferase involved in the pathway to 2-deoxystreptamine. J Chem Soc Chem Commun: 2860-2861 (2002)

15. Yokoyama K, Kudo F, Kuwahara M, Inomata K, Tamegai H, Eguchi T, Kakinuma K. Stereochemical recognition of doubly functional aminotransferase in 2-deoxystreptamine biosynthesis. J Am Chem Soc 127: 5869-5874 (2005)

16. Kudo F, Kawabe K, Kuriki H, Eguchi T, Kakinuma K. A new family of glucose-1-phosphate/glucosamine-1phosphate nucleotidylyltransferase in the biosynthetic pathways for antibiotics. J Am Chem Soc 127: 1711-1718 (2005)

17. Kharel MK, Basnet DB, Lee HC, Liou K, Woo JS, Kim BG, Sohng JK. Isolation and characterization of the tobramycin biosynthetic gene cluster from Streptomyces tenebrarius. FEMS Microbiol Lett 230: 185-190 (2004)

18. Kharel MK, Basnet DB, Lee HC, Liou K, Moon YH, Kim J-J, Woo JS, Sohng JK. Molecular cloning and characterization of a 2-deoxystreptamine biosynthetic gene cluster in gentamicin-producing Micromonospora echinospora ATCC15835. Mol Cells 18: 71-78 (2004)

19. Kharel MK, Subba B, Basnet DB, Woo JS, Lee HC, Liou K, Sohng JK. A gene cluster for biosynthesis of kanamycin from Streptomyces kanamyceticus: comparison with gentamicin biosynthetic gene cluster. Arch Biochem Biophys 429: 204-214 (2004)

20. Unwin J, Standage S, Alexander D, Hosted T Jr, Horan AC, Wellington EMH. Gene cluster in Micromonospora echinospora ATCC15835 for the biosynthesis of the gentamicin C complex. J Antibiot 57: 436-445 (2004)
21. Yanai K, Murakami T. The kanamycin biosynthetic gene cluster from Streptomyces kanamyceticus. J Antibiot 57: 351-354 (2004)

22. Huang F, Haydock SF, Mironenko T, Spiteller D, Li Y, Spencer JB. The neomycin biosynthetic gene cluster of Streptomyces fradiae NCIMB 8233: characterisation of an aminotransferase involved in the formation of 2deoxystreptamine. Org Biomol Chem 3: 1410-1418 (2005)

23. Subba B, Kharel MK, Lee HC, Liou K, Kim B-G, Sohng JK. The ribostamycin biosynthetic gene cluster in Streptomyces ribosidificus: Comparison with butirosin biosynthesis. Mol Cells 20: 90-96 (2005)

24. Tamegai H, Eguchi T, Kakinuma K. First identification of Streptomyces genes involved in the biosynthesis of 2deoxystreptamine-containing aminoglycoside antibiotics genetic and evolutionary analysis of L-glutamine:2-deoxyscyllo-inosose aminotransferase genes. J Antibiot 55: 1016-1018 (2002)

25. Suzukake K, Tokunaga K, Hayashi H, Hori M, Uehara Y, Ikeda D, Umezawa H. Biosynthesis of 2-deoxystreptamine. J Antibiot 38: 1211-1218 (1985)

26. Yamauchi N, Kakinuma K. Confirmation of in vitro synthesis of 2-deoxy-scyllo-inosose, the earliest intermediate in the biosynthesis of 2-deoxystreptamine, using cell free preparations of Streptomyces fradiae. J Antibiot 45: 774-780 (1992)

27. Banfield MJ, Salvucci ME, Baker EN, Smith CA. Crystal structure of the $\operatorname{NADP}(\mathrm{H})$-dependent ketose reductase from Bemisia argentifolii at $2.3 \AA$ resolution. J Mol Biol 306: 239-250 (2001)

28. Levin I, Meiri G, Peretz M, Burstein Y, Frolow F. The ternary complex of Pseudomonas aeruginosa alcohol dehydrogenase with NADH and ethylene glycol. Protein Sci 13: 1547-1556 (2004)

29. Ceccarelli C, Liang ZX, Strickler M, Prehna G, Goldstein BM, Klinman JP, Bahnson BJ. Crystal structure and amide H/D exchange of binary complexes of alcohol dehydrogenase from Bacillus stearothermophilus: insight into thermostability and cofactor binding. Biochemistry 43: 5266-5277 (2004)

30. Sambrook J, Fritsch EF, Maniatis T. Molecular cloning. A laboratory manual. 2 nd edn, Cold Spring Harbor Laboratory, Cold Spring Harbor NY (1989)

31. Bierman M, Logan R, O’Brien K, Seno ET, Rao RN, Schoner BE. Plasmid cloning vectors for the conjugal transfer of DNA from Escherichia coli to Streptomyces spp. Gene 116: 43-49 (1992)

32. Kieser T, Bibb MJ, Buttner MJ, Chater KF, Hopwood DA. Practical Streptomyces Genetics. The John Innes Foundation Centre, John Innes Centre, Norwich Research Park, Colney, Norwich NR4 7UH, England (2000)

33. Ishikawa J, Hotta K. FramePlot: a new implementation of the frame analysis for predicting protein-coding regions in bacterial DNA with a high $\mathrm{G}+\mathrm{C}$ content. FEMS Microbiol Lett 174: 251-253 (1999) 